\title{
PENGARUH PEMAKAIAN MEDIA PAPAN TKP (TEMPAT KEJADIAN PERKARA) TERHADAP KEMAMPUAN BERCERITA
}

\author{
Elfy Rachmanita
}

SMA Negeri 1 Singosari Malang

Email: elfyrachmanita@yahoo.com

\begin{abstract}
ABSTRAK
Penelitian ini bertujuan untuk mengetahui pengaruh penggunaan media papan TKP (Tempat Kejadian Perkara) terhadap kejelasan vokal dan intonasi, kelancaran berbicara, dan keruntutan alur cerita siswa saat bercerita. Penelitian ini menggunakan pendekatan penelitian kuantitatif dengan desain penelitian eksperimen semu. Hasil penelitiannya sebagai berikut. Pertama, ada pengaruh penggunaan media papan TKP (Tempat Kejadian Perkara) terhadap kejelasan vokal dan intonasi siswa saat bercerita. Kedua, ada pengaruh penggunaan media papan TKP (Tempat Kejadian Perkara) terhadap kelancaran berbicara siswa saat bercerita. Ketiga, ada pengaruh penggunaan media papan TKP (Tempat Kejadian Perkara) terhadap keruntutan alur cerita siswa saat bercerita.
\end{abstract}

Kata Kunci: media papan TKP (Tempat Kejadian Perkara), kemampuan bercerita, pembelajaran bercerita

\begin{abstract}
The purpose of this research is to know the influence of TKP (crime scene) media on vocal clearence and intonation, speaking fluency and the coherence of the storytelling capability. The method of the research is by using quntitative descriptive approach with quasy-experimental design. The results of the research can be described as follows: first, the influence of TKP (crime scene) board to vocal clearence and intonation of the speaking. Second, the influence of TKP (crime scene) board media to speaking fluency of the students. Third, the influence of TKP (crime scene) board media to the coherence of the storytelling.
\end{abstract}

Keywords: TKP (crime scene) board, tellingstory capability, tellingstory learning

\section{PENDAHULUAN}

Keterampilan bercerita merupakan keterampilan yang penting untuk dilatihkan kepada siswa karena keterampilan bercerita dapat menjadi sarana untuk mendidik dan menyampaikan pesan moral kepada siswa. Selain itu, keterampilan bercerita juga dapat membantu perkembangan bahasa siswa. Bercerita merupakan batu loncatan penting dalam membentuk karakter seorang anak. Bercerita memicu kekuatan berpikir yang super, yang melepaskan perperimajinasi seseorang. Menurut ahli psikologi anak, pertumbuhan mental seorang anak berjalan sangat cepat, terutama sampai anak berusia dua belas tahun kecepatan belajar anak bagai kuda yang berlomba dalam pacuan. Setelah melewati usia ini, kecepatan belajar anak akan menurun, dan lebih mendatar (Shakuntala, 2011:9-10).

Berdasarkan hasil penelitian yang telah dilakukan Masruroh (2007) dengan judul Kemampuan Bercerita Siswa Kelas VII SMP Negeri 4 Malang dengan Menggunakan Kelompok Teater di- 
simpulkan bahwa kemampuan bercerita siswa masih di bawah nilai ketuntasan 75 . Salah satu penyebab rendahnya kemampuan bercerita siswa adalah karena kurang menarik dan efektifnya media pembelajaran yang digunakan. Nurgiyantoro (2001:128) menyatakan bahwa media pengajaran dapat mempertinggi proses belajar siswa karena media pengajaran akan menarik perhatian siswa, bahan pengajaran akan lebih jelas maknanya, metode mengajar menjadi lebih bervariasi, dan siswa akan lebih banyak melakukan kegiatan belajar. Hal ini dibuktikan dengan penelitian yang telah dilakukan oleh Asteria (2010) berjudul Pengaruh Penggunaan Media Wayang Karton terhadap Kemampuan Bercerita Siswa Kelas VII SMP Negeri 17 Malang Tahun Pelajaran 2010/2011 yang menyimpulkan bahwa media wayang karton memiliki pengaruh positif terhadap kemampuan bercerita siswa dari aspek intonasi dan kelancaran berbicara. Oleh sebab itu, dibutuhkan sebuah media yang dapat membantu siswa menyampaikan pikiran dan perasaannya.

Salah satu media yang dapat digunakan saat bercerita adalah media papan TKP (Tempat Kejadian Perkara). Media papan TKP (Tempat Kejadian Perkara) merupakan sebuah media yang terbuat dari papan yang berlapis kain flanel. Papan tersebut telah diseting sesuai dengan latar tempat pada cerita. Papan tersebut juga dilengkapi dengan semua tokoh yang terlibat dalam cerita rakyat yang disampaikan dan ornamen pendukung (pohon-pohonan, awan, gunung, danau, dan istana). Tokoh-tokoh dan ornamen yang ada dapat ditempel dan dilepas dengan mudah, sehingga pencerita mudah dalam menggunakan media ini. Selain itu dengan adanya background yang menjadi setting cerita, tokoh-tokoh dalam cerita, dan ornamen pendukung cerita pendongeng akan lebih menjiwai isi cerita yang ia sampaikan.

Berdasarkan latar belakang di atas, penelitian ini mengangkat judul Pengaruh Penggunaan Media Papan TKP (Tempat Kejadian Perkara) terhadap Kemampuan Bercerita Siswa. Penelitian ini bertujuan untuk mengetahui (1) pengaruh penggunaan media papan TKP (Tempat Kejadian Perkara) terhadap kejelasan vokal dan intonasi siswa saat bercerita, (2) pengaruh penggunaan media papan TKP (Tempat Kejadian Perkara) terhadap kelancaran berbicara siswa saat bercerita, dan (3) pengaruh penggunaan media papan TKP (Tempat Kejadian Perkara) terhadap keruntutan alur cerita siswa saat bercerita.

\section{METODE}

Penelitian ini menggunakan pendekatan kuantitaf dengan desain penelitian eksperimen semu. Desain penelitian eksperimen semu ini menggunakan rancangan pretest-posttest group. Variabel penelitian ini adalah media papan TKP (Tempat Kejadian Perkara) sebagai variabel bebas dan kemampuan bercerita sebagai variabel terikat. Pada rancangan pretest-posttest group ini, kelompok kontrol dan kelompok eksperimen dites untuk dilihat kemampuan awal berceritanya sebelum diberikan perlakuan. Kemudian kelompok eksperimen diberikan perlakuan menggunakan media papan TKP (Tempat Kejadian Perkara) sedangkan kelompok kontrol tidak. Setelah perlakuan diberikan, kedua kelompok tersebut dites kembali untuk dilihat perbedaanya. Pengujian tentang pengaruh dilakukan dengan membedakan antara hasil posttest kelompok kontrol dan kelompok eksperimen, dengan asumsi bahwa hasilnya harus sama dan kalau terjadi perbedaan 
maka itu disebabkan oleh perlakuan/ variabel bebas dalam eksperimen.

Sumber data penelitian ini adalah rekaman performansi siswa kelas eksperimen dan kelas kontrol saat bercerita. Populasi penelitian ini adalah seluruh siswa kelas VII SMPN 11 Malang yang berjumlah 280 siswa, sedangkan sampel yang diambil adalah siswa kelas VII 2 sebagai kelas eksperimen dan siswa kelas VII 5 sebagai kelas kontrol yang berjumlah 60 siswa. Pengambilan sampel dilakukan dengan teknik Random Sampling dengan asumsi bahwa populasi bersifat homogen dilihat dari lingkungan kelas siswa, guru yang mengajar, beban pelajaran siswa dan tempat tinggal siswa yang tidak jauh berbeda.

Penelitian ini menggunakan tiga instrumen untuk mengumpulkan data yaitu perintah dan petunjuk tes performansi, rubrik penilaian, dan alat perekam. Instrumen penelitian perintah dan petunjuk tes performansi dan alat perekam digunakan untuk menjaring sumber data berupa rekaman performansi siswa saat bercerita. Rubrik penilaian digunakan untuk menjaring data berupa skor kemampuan siswa dalam bercerita dari aspek kejelasan vokal, kelancaran berbicara, dan keruntutan alur.

Pengumpulan data penelitian dilakukan dengan memberikan tes awal dan tes akhir bercerita. Tahapan pengumpulan data penelitian ini meliputi (1) permohonan izin kepada kepala sekolah untuk melakukan penelitian, (2) penyusunan instrumen, (3) uji coba instrumen, (4) prestest bercerita pada kelas kontrol dan kelas eksperimen, (5) uji normalitas dan homogenitas data, (6) pembelajaran bercerita seperti biasa pada kelas kontrol, (7) perlakuan dengan menggunakan media papan TKP (Tempat Kejadian Perkara) pada kelas eksperimen. Perlakuan tersebut berupa pembuatan media papan TKP (Tempat Kejadian Perkara) dan latihan menggunakan media papan TKP (Tempat Kejadian Perkara), (8) postest bercerita, (9) uji hipotesis menggunakan teknik Independent Sample t-test.

Data penelitian ini adalah skor pretest dan posttest yang menggambarkan kemampuan bercerita siswa dari kelas eksperimen dan kelas kontrol pada aspek kejelasan vokal dan intonasi, kelancaran berbicara, dan keruntutan alur cerita. Data tersebut diperoleh dari skor performansi siswa ketika bercerita yang dinilai menggunakan rubrik penilaian bercerita siswa.

Peneliti melakukan dua tahap analisis data untuk mengetahui pengaruh penggunaan media papan TKP (Tempat Kejadian Perkara) terhadap kejelasan vokal dan intonasi, kelancaran berbicara, dan keruntutan alur cerita siswa saat bercerita. Teknik yang digunakan untuk menganlisis data adalah teknik t-tes dengan taraf siginifikan $\mathrm{a}=0,05$ menggunakan aplikasi SPSS 16.0. Analisis yang pertama adalah menguji homogenitas data menggunakan teknik Independent Sample t-test dan uji normalitas data menggunkan uji Kolmogrov-Smirnov pada kelompok kontrol dan kelompok eksperimen. Analisis yang kedua adalah menguji hipotesis yang diajukan yaitu terdapat pengaruh signifikan penggunaan media papan TKP (Tempat Kejadian Perkara) terhadap kemampuan bercerita siswa. Teknik statistik yang digunakan untuk menguji hipotesis tersebut adalah teknik Independent Sample t-test, yang diuji adalah perbedaan skor posttest kemampuan bercerita antara kelompok kontrol dengan kelompok eksperimen. Jika Sig:p $<0,05$ maka Ha diterima dan jika Sig:p > 0,05 maka Ha ditolak. 


\section{HASIL DAN PEMBAHASAN}

Berdasarkan analisis data, dihasilkan tiga temuan, yaitu (1) kejelasan vokal dan intonasi siswa saat bercerita, (2) kelancaran berbicara siswa saat bercerita, dan (3) keruntutan alur cerita siswa saat bercerita.

Pertama, kejelasan vokal dan intonasi siswa saat bercerita. Berdasarkan hasil analisis statistik diketahui mean kelas kontrol adalah 68,3 sedangkan mean kelas eksperimen adalah 79,4 dan thitung adalah 8.915, $\mathrm{p}=0,008(\mathrm{p}<0,05)$. Berdasarkan hasil tersebut dapat disimpulkan terdapat perbedaan antara skor kejelasan vokal dan intonasi sampel pada kelas kontrol dengan kelas eksperimen. Dengan demikian dapat disimpulkan bahwa ada pengaruh signifikan penggunaan media papan TKP (Tempat Kejadian Perkara) terhadap kemampuan bercerita siswa dari kejelasan kejelasan vokal dan intonasi.

Kedua, kelancaran berbicara siswa saat bercerita. Berdasarkan hasil analisis statistik diketahui mean kelas kontrol adalah 69 sedangkan mean kelas eksperimen adalah 88,5 dan thitung adalah 8.016, $\mathrm{p}=0,000(\mathrm{p}<0,05)$. Berdasarkan hasil tersebut dapat disimpulkan terdapat perbedaan antara skor kejelasan vokal dan intonasi sampel pada kelas kontrol dengan kelas eksperimen. Dengan demikian dapat disimpulkan bahwa ada pengaruh signifikan penggunaan media papan TKP (Tempat Kejadian Perkara) terhadap kemampuan bercerita siswa dari kelancaran berbicara.

Ketiga, keruntutan alur cerita siswa saat bercerita. Berdasarkan hasil analisis statistik diketahui mean kelas kontrol adalah 68,3 sedangkan mean kelas eksperimen adalah 79,4 dan thitung adalah 3.900, $\mathrm{p}=0,003(\mathrm{p}<0,05)$. Berdasarkan hasil tersebut dapat disimpulkan terdapat perbedaan antara skor kejelasan vokal dan intonasi sampel pada kelas kontrol dengan kelas eksperimen. Dengan demikian dapat disimpulkan bahwa ada pengaruh signifikan penggunaan media papan TKP (Tempat Kejadian Perkara) terhadap kemampuan bercerita siswa dari aspek keruntutan alur cerita.

\section{Pengaruh Penggunaan Media Papan TKP (Tempat Kejadian Perkara) terhadap Kejelasan Vokal dan Intonasi Siswa saat Bercerita}

Ada pengaruh penggunaan media papan TKP (Tempat Kejadian Perkara) terhadap kejelasan vokal dan intonasi siswa saat bercerita. Perbedaan kejelasan vokal dan intonasi siswa dapat dilihat dari hasil perbandingan bercerita siswa pada kelas kontrol dan kelas eksperimen. Pada siswa kelompok eksperimen yang telah mendapatkan perlakuan berupa penggunaan media papan TKP (Tempat Kejadian Perkara), dapat diamati bahwa intonasi dalam bercerita sebagian besar siswa sudah tepat. Hal ini ditunjukkan ketika siswa pada kelas eksperimen menggunakan nada kalimat, penekanan, dan tempo yang sesuai dengan isi cerita. Penggunaan intonasi yang tepat sangat membantu keefektifan dan keberhasilan kegiatan bercerita seperti yang disampaikan Widyamartaya (1984:41) "Intonasi wicara kita dapat membantu efektivitas wicara kita, maka keberhasilan dalam hal wicara banyak dipengaruhi oleh intonasi kita."

Ketepatan intonasi pada kelompok eksperimen disebabkan tokoh-tokoh pada papan TKP (Tempat Kejadian Perkara) dapat ditempel dan dilepas dengan mudah sesuai dengan seting dialognya dan siapa lawan dialognya. Hal ini membuat kegiatan bercerita menjadi hidup sehingga dialogdialog yang diucapkan menggunakan intonasi yang sesuai, bahkan siswa pada 
kelompok eksperimen dapat berdialog dengan warna suara yang berbeda, sehingga pendengar lebih tertarik dan lebih memahami isi cerita. Warna suara harus dapat dibuat bervariasi karena variasi ini akan membuat cerita lebih enak didengar dan lebih mudah diikuti serta dipahami (Widyamartaya, 1984:34).

Penggunaan media papan TKP (Tempat Kejadian Perkara) pada kelompok eksperimen juga mendukung siswa agar dapat bercerita dengan menggunakan pelafalan yang tepat dan intonasi yang tepat pula. Hal ini disebabkan karakter tokohtokoh pada papan TKP (Tempat Kejadian Perkara) dibuat sama dengan karakter yang terdapat pada cerita, misalnya karakter Rupaksa pada cerita Asal-usul Nama Kota Banyuwangi merupakan karakter antagonis dan pada tokoh flanel karakter tersebut ditunjukkan dengan alis yang sengaja disatukan dan bibir yang dibentuk segitiga sehingga dapat terlihat tokoh pada flanel juga memiliki karakter antagonis. Dengan adanya ekspresi pada tokoh flanel, maka siswa akan berfikir untuk melafalkan kata dengan jelas dan menggunakan intonasi yang sesuai dengan karakter antagonis pula. Masdiono (2004:131) menyatakan bahwa simbol-simbol kartun berbentuk karakter secara bertahap berkembang dari bentuk gambar ke bentuk bahasa modern yang abstrak, dan akhirnya sampai kepada sistem berdasarkan bunyi yang benar-benar abstrak.

Pada siswa kelompok kontrol yang tidak mendapatkan perlakuan dapat diamati bahwa masih banyak kesalahan pada aspek intonasi. Kesalahan intonasi yang dilakukan oleh siswa berupa banyaknya kalimat yang tinggi rendahnya, panjang pendeknya, keras lembutnya suara, atau penjedaan kalimat kurang sesuai dengan isi cerita.

\section{Pengaruh Penggunaan Media Papan TKP (Tempat Kejadian Perkara) terhadap Kelancaran Berbicara Siswa saat Bercerita}

Ada pengaruh penggunaan media papan TKP (Tempat Kejadian Perkara) terhadap kelancaran berbicara siswa saat bercerita. Perbedaan kelancaran berbicara dapat dilihat dari hasil perbandingan bercerita siswa pada kelas kontrol dan kelas eksperimen. Kelancaran bercerita pada kelas eksperimen ditunjukkan dengan penyampaian yang tidak menggunakan bunyi penyela, tempo yang tidak terlalu cepat ataupun terlalu lambat, tidak menimbulkan kesulitan pemahaman, dan kalimat disampaikan dengan struktur yang logis.

Salah satu aspek yang dinilai dalam berbicara adalah kelancaran yang terkait dengan kefasihan dan kelancaran bercerita (Nurgiyantoro, 2001:161). Seringkali pada kelas kontrol terdengar bunyi-bunyi penyela saat bercerita, misalnya “emm”, “apa ya?”, “aa”, dan lain-lain. Seorang pembicara yang lancar akan memudahkan pendengar menangkap pembicaraannya, sebaliknya pembicara yang terlalu cepat berbicara juga akan menyulitkan pendengar menangkap pokok pembicaraannya (Arsyad, 1987:21).

Salah satu faktor yang mempengaruhi kelancaran berbicara adalah pengalaman. Pengalaman berbicara menyebabkan seseorang lebih lancar berbicara. Lihat saja seorang guru atau dosen, mereka sudah berpengalaman dalam berbicara sehingga ketika mereka berbicara seperti sudah mengalir dengan sendirinya (Rogers, 2003:30). Pengalaman berbicara ini telah dilakukan melalui pembelajaran bercerita menggunakan media papan TKP (Tempat Kejadian Perkara). Tokoh-tokoh pada papan TKP (Tempat Kejadian Perkara) 
dibuat sendiri oleh siswa sehingga siswa benar-benar memahami isi cerita, tokoh dan juga karakternya. Kemudian siswa diminta guru untuk berlatih bercerita menggunakan media papan TKP (Tempat Kejadian Perkara) secara berkelompok. Latihan yang dilakukan oleh siswa inilah yang dapat dimasukkan ke dalam faktor pengalaman. Dengan berlatih, siswa memiliki pengalaman bercerita, sehingga mereka mengetahui kesulitan-kesulitan bercerita dan cara mengatasinya. Rasa percaya diri juga terbentuk mealui latihanlatihan yang cukup. Betapapun kerasnya usaha meyakinkan diri sendiri mampu berbicara dengan baik di depan publik, tanpa pelatihan kemungkinan besar jantung akan berdetak keras dan ingatan tiba-tiba hilang saat mulai berbicara (Rogers, 2003:30).

Media papan TKP (Tempat Kejadian Perkara) yang berisi tokoh-tokoh pada cerita juga dapat membantu siswa lebih mudah dalam menyusun kalimat-kalimat yang logis saat bercerita. Tokoh-tokoh dalam berbagai ragam boneka merupakan media yang efektif untuk melatih siswa agar lebih mudah dalam membuat kalimat (Saksomo, 2001:80).

\section{Pengaruh Penggunaan Media Papan TKP (Tempat Kejadian Perkara) terhadap Keruntutan Alur Cerita Siswa saat Bercerita}

Ada pengaruh penggunaan media papan TKP (Tempat Kejadian Perkara) terhadap keruntutan alur cerita siswa saat bercerita. Perbedaan keruntutan alur cerita dapat dilihat dari hasil perbandingan bercerita siswa pada kelas kontrol dan kelas eksperimen. Siswa pada kelas eksperimen sudah dapat bercerita dengan alur yang runtut dan lengkap. Hal ini dapat dilihat ketika siswa bercerita dengan menyebutkan semua unsur cerita yang ada dalam cerita rakyat secara lengkap, dan menceritakan peristiwa-peristiwa yang ada dalam cerita urut dari awal hingga akhir.

Penggunaan media papan TKP (Tempat Kejadian Perkara) pada kelompok eksperimen mempengaruhi siswa dalam menyebutkan semua tokoh dan peristiwa yang ada dalam cerita secara runtut. Dengan adanya papan TKP (Tempat Kejadian Perkara), siswa lebih mudah mengingat tokoh-tokoh yang ada dalam cerita, sehingga memperkecil kemungkinan lupa terhadap cerita karena mereka bercerita sambil memerankan tokoh-tokoh flanel tersebut pada papan TKP (Tempat Kejadian Perkara). Hal ini sejalan dengan yang disampaikan Arsyad (2010:25) "Manfaat media visual gambar hidup menumbuhkan pemikiran yang teratur dan kontinyu."

Selain itu, sebelum memulai bercerita, siswa juga sudah mengurutkan letak tokoh dan ornamen-ornamen yang mendukung seting cerita, sehingga ketika melihat urutan tokoh-tokoh tersebut siswa akan segera ingat jalan ceritanya. Oleh karena itu, papan TKP (Tempat Kejadian Perkara) sangat efektif untuk membuat siswa dapat bercerita dengan menyebutkan semua unsur cerita yang ada dalam cerita rakyat secara lengkap dan menceritakan peristiswaperistiwa yang ada dalam cerita secara urut dari awal hingga akhir seperti yang disampaikan Arsyad (2010:91) "Media visual dapat memperlancar pemahaman (misalnya melalui elaborasi struktur dan organisasi) dan memperkuat ingatan."

Pada siswa kelompok kontrol yang tidak mendapat perlakuan, dapat diamati bahwa masih banyak siswa yang belum dapat bercerita dengan alur yang runtut dan lengkap. Hal ini ditunjukkan ketika siswa tiba-tiba berhenti bercerita dan 
mencoba mengingat-ingat jalan ceritanya, hingga akhirnya ada beberapa siswa yang menghilangkan beberapa peristiwa yang tidak mereka ingat, seperti pada cerita danau toba, ada 8 siswa yang tidak menyebutkan tokoh gadis yang mengajak toba bermain layang-layang. Pada cerita “Asal Mula Air Terjun Coban Rondo” ada 11 siswa yang tidak menceritakan peristiwa seorang emban atau pembantu yang mengajak Dewi Anjarwati bersembunyi di bawah air terjun. Pada cerita Rara Jonggrang, ada 4 siswa yang tidak menyebutkan peristiwa ketika para jin kalang kabut hendak meninggalkan proses pembangunan candi karena para jin mengira bahwa hari telah pagi padahal peristiwa ini sangat penting pada kisah Rara Jonggrang karena bagian ini adalah klimaks dari cerita tersebut.

\section{SIMPULAN}

Berdasarkan hasil penelitian dan pembahasan yang telah dikemukakan dapat ditarik kesimpulan mengenai: (1) pengaruh penggunaan media papan TKP (Tempat Kejadian Perkara) terhadap kejelasan vokal dan intonasi siswa kelas VII SMPN 11 Malang saat bercerita, (2) pengaruh penggunaan media papan TKP (Tempat Kejadian Perkara) terhadap kelancaran berbicara siswa SMPN 11 Malang saat bercerita dan (3) pengaruh penggunaan media papan TKP (Tempat Kejadian Perkara) terhadap keruntutan alur cerita siswa kelas VII SMPN 11 Malang saat bercerita.

Pertama, media papan TKP (Tempat Kejadian Perkara) berpengaruh terhadap kejelasan vokal dan intonasi siswa saat bercerita. Pengaruh tersebut dijabarkan lagi menjadi lebih rinci yaitu, 1) media papan TKP (Tempat Kejadian Perkara) berpengaruh terhadap kejelasan volume suara siswa, 2) media papan TKP (Tempat Kejadian Perkara) berpengaruh terhadap pelafalan vokal siswa, 3) media papan TKP (Tempat Kejadian Perkara) berpengaruh terhadap pelafalan konsonan siswa, 4) media papan TKP (Tempat Kejadian Perkara) berpengaruh terhadap kemampuan membedakan warna suara siswa, 5) media papan TKP (Tempat Kejadian Perkara) berpengaruh terhadap ketepatan penjedaan frasa siswa, 6) media papan TKP (Tempat Kejadian Perkara) berpengaruh terhadap ketepatan nada kalimat siswa, 7) media papan TKP (Tempat Kejadian Perkara) berpengaruh terhadap penekanan kata siswa.

Kedua, media papan TKP (Tempat Kejadian Perkara) berpengaruh terhadap kelancaran berbicara siswa. Pengaruh tersebut dijabarkan menjadi lebih rinci lagi yaitu, 1) media papan TKP (Tempat Kejadian Perkara) berpengaruh terhadap kelogisan kalimat siswa, 2) media papan TKP (Tempat Kejadian Perkara) berpengaruh terhadap penggunaan bunyi penyela siswa, 3) media papan TKP (Tempat Kejadian Perkara) berpengaruh terhadap tempo berbicara siswa, 4) media papan TKP (Tempat Kejadian Perkara) berpengaruh terhadap pemahaman pada isi cerita.

Ketiga, media papan TKP (Tempat Kejadian Perkara) berpengaruh terhadap keruntutan alur cerita siswa. Keruntutan alur cerita tersebut meliputi kemampuan menyebutkan semua tokoh dalam cerita, semua peristiwa yang terjadi, dan kemampuan bercerita dengan jalan cerita yang runtut. Saran bagi guru mata pelajaran Bahasa Indonesia sebagai fasilitator, sebaiknya menggunakan media papan TKP (Tempat Kejadian Perkara) pada pembelajaran bercerita karena media papan TKP (Tempat Kejadian Perkara) 
terbukti dapat mendorong siswa untuk menghasilkan warna suara yang berbedabeda untuk setiap karakter tokoh dalam sebuah cerita. Kemampuan menghasilkan beragam jenis suara ini sangat penting untuk menunjang performansi seseorang ketika bercerita. Selain itu, sebaiknya guru memberikan kesempatan yang lebih luas kepada siswa untuk berlatih bercerita agar siswa memiliki lebih banyak pengalaman belajar karena pengalaman tersebut dapat meningkatkan kelancaran berbicara siswa. Latihan bercerita ini dapat dilakukan di sela-sela pembelajaran atau di akhir pembelajaran untuk mengurangi kejenuhan siswa. Selain latihan bercerita, penanaman pengalaman belajar berbicara siswa juga dapat dilakukan dengan memberikan kesempatan kepada siswa untuk membuat media pembelajaran bercerita secara mandiri.

\section{DAFTAR PUSTAKA}

Arsyad, A. 2010. Media Pembelajaran. Jakarta: Putra Utama Offset.

Asteria, P. V. 2010. Pengaruh Penggunaan Media Wayang Karton terhadap Kemampuan Bercerita Siswa Kelas VII SMP Negeri 17 Malang Tahun Pelajaran 2010/ 2011. Skripsi tidak diterbitkan. Malang: Universitas Negeri Malang.
Masdiono, T. 2004. Memahami Komik. Jakarta: Gramedia Pustaka Utama

Masruroh, D. Y. 2007. Kemampuan Bercerita Siswa Kelas VII SMP Negeri 4 Malang dengan Menggunakan Kelompok Teater. Skripsi tidak diterbitkan. Malang: Universitas Negeri Malang.

Nurgiyantoro, B. 2001. Penilaian Pembelajaran Bahasa Berbasis Kompetensi. Yogyakarta: BPFE.

Rogers, N. 2003. Berani Berbicara di Depan Publik. Bandung: Nuansa Cendekia.

Saksomo, D. 2001. Berbicara Lanjut. Malang: IKIP Malang.

Shakuntala, D. 2011. Jadikan Anak Anda

Jenius. Jakarta: Gramedia Pustaka Utama.

Widyamartaya, A. 1984. Kreatif Berwicara. Yogyakarta: Yayasan Kanisius. 